\title{
動力学的干渉を利用した移動マニピュレータの波状路走行
}

\section{Mobile Manipulator travel waved road using dynamical interference}

\author{
○非玉村篤士(福井大)，，正 見浪 護 (福井大) \\ 正 朝倉 俊行 (福井大)
}

\author{
Atsushi TAMAMURA, Fukui University, Bunkyou 3-9-1, Japan \\ Mamoru MINAMI, Fukui University, Bunkyou 3-9-1, Japan \\ Toshiyuki ASAKURA, Fukui University, Bunkyou 3-9-1, Japan
}

Key Words: Mobile Manipulator, Motion Intelligence, Fourier Series, Genetic Algorithm, Waved Road

\section{1 緒言}

現在各種作業現場で稼動しているロボットのほとんど は, 移動型と固定型に分ける事が出来る.そして移動型 においてその移動は, 移動する事を目的とした駆動部（車 輪，キャタピラ等）のみを利用する事が前提となつてい る. 又, 作業部より生ずる各部分への動力学的干渉を, 作 業を行う上での正確さを妨げるものとして排除するよう 努められている.しかし，人間は両腕の振りを走ったり， 跳んだりする時に有効に利用する事ができる。このよう な動力学的干渉を利用する事は, ロボットの総合的な運 動能力を向上する事が出来る可能性があると考えられる. そこで，我々はこれまでに移動用動力装置を持たない移 動マニピュレータモデルを対象とし，水平路面において 車載リンクの運動による動力学的干涉を利用した移動マ ニピュレータの走行を実現してきた 1)2)。 （そしてこの時 走行を実現する車載リンクの運動パターンを機械自身に 探索させる事で，運動知能を獲得する方法とした。本報 では，移動用動力装置を持たない移動マ三ピュレータモ デルを対象とし，これまでに提案した運動知能を獲得す る方法を利用して, 波状路面において移動を可能とする 車載リンクの運動パ夕ーンの獲得を目的とする。

\section{2 運動知能の定義}

本報では，機械に運動知能を与える手法を提案してい る.ここで，提案している運動知能の定義とその獲得に 関する仮定を行う。人は走るときに腕の振りを利用して より速く走ることができる。これは腕の動きによる動力 学的干涉を，速く走ることに利用していると考えられる. 本来, 速く走るという目的は, 両足を動かすことで実現 される.しかし直接には作用しない両腕の振りも速く走 るという目的に対して利用できることを人間は知ってい る.このときの腕の振り方は誰かに直接指導されたわけ ではなく自分自身の成長過程において意識・無意識に関わ らず学習していく.この学習には次の3つの条件が考え られる. 1. 運動目的, 2 . 身体的特徵，3. 環境，であ る. 運動目的とは運動を行う目的であり，例えば速く走 ること，長距離を走ること等である。速く走る事を要求 されれば速く走ろうとし，長距離を走る事を要求されれ ば疲れにくい走り方を学んでいく。この時体は成長に伴 い足の長さや腕の長さ，筋力や体重などが変化する。 ケ ガなどをしていればその部分を庇うこともある.人間は この変化する体を用いて目的を達成する動き方を学習す る.このとき腕の長さや足の長さなどの個人固有の内部 条件を身体的特幑とする。そして，走っているときの路 面状況や天候，障害物等が運動を行う外部の環境とする. これらの”運動目的”, “身体的特徵”, “環境”を用い 本報では運動知能を次のように考える。およそ全ての動 物や人間は，その生れ落ちた睘境亡自分の身体的特幑の もとで，運動目的に沿う合理的な運動パターンを学習し， 獲得していく能力を備えている.このような運動パター ンの学習システムを生物の運動知能と考える.

\section{3 モデリング}

Fig.1に，シミュレーションのためにモデル化する波状 路面を走行する1リンク移動マニピュレータの実機を示 す.この 1 リンク移動マニピュレータは, 移動用に駆動 部を持たず，また停止用のブレーキも持たない。1リン ク移動マニピュレー夕の移動は, 車載リンクの振幅運動 による干渉にのみ誘発される。、シミュレーションを行う ために, Fig.1に示す実機の各パラメータを Fig.2 のよう に規定する. そして, 波状路面を走行する 1 リンク移動 マニピュレータの運動方程式を式 (1) に示す3)4).

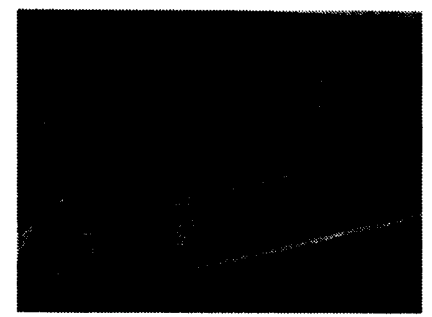

Fig. 1: Mobile Manipulator

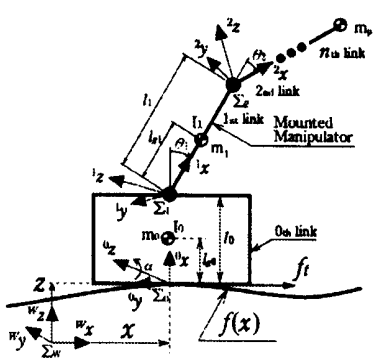

Fig. 2: Model

$$
\begin{aligned}
\boldsymbol{M} \ddot{\boldsymbol{p}} & +\boldsymbol{h}+\boldsymbol{g}+\boldsymbol{D} \\
& =\boldsymbol{\tau}_{M}+\boldsymbol{U}_{t} f_{t}+\boldsymbol{U}_{n} \boldsymbol{R}^{-1}\left[-\frac{\partial}{\partial \boldsymbol{p}}\left(\frac{\partial \boldsymbol{C}}{\partial \boldsymbol{p}} \dot{\boldsymbol{p}}\right) \dot{\boldsymbol{p}}\right. \\
& \left.+\frac{\partial \boldsymbol{C}}{\partial \boldsymbol{p}} \boldsymbol{M}^{-1}\left\{\boldsymbol{h}+\boldsymbol{g}+\boldsymbol{D}-\boldsymbol{\tau}_{M}-\boldsymbol{U}_{t} f_{t}\right\}\right]
\end{aligned}
$$

ここで, 波状路面を走行する 1 リンク移動マニピュレー 夕の一般化座標ベクトルを $p=\left[x, z, \alpha, \theta_{1}\right]^{T}$ とする. $x, z$ は台車部の重心座標, $\alpha$ は台車部の傾き, $\theta_{1}$ は車載リン クの傾きを表す. 式 (1) において, 入力トルクは $\tau_{M}=$ $\left[0,0,0, \tau_{1}\right]^{T}$ で表され, $\boldsymbol{M}(\boldsymbol{p})$ は慣性力, $\boldsymbol{h}(\boldsymbol{p}, \dot{\boldsymbol{p}})$ は遠心 力・コリオリカ, $\boldsymbol{g}(\boldsymbol{p})$ は重力をせれぞれ表す。摩擦力を 表す $\boldsymbol{D}(\dot{\boldsymbol{p}})=\left[d_{x}, d_{z}, 0, d_{1}\right]^{T}$ の各要素は式 (2), 式 (4), 式 (5)より近似的に表している ${ }^{5)}$. 又, 式 (2), 式 (5)にお ける $\mu_{v}, \mu_{1}$ は粘性摩擦係数を表し, 式 (2)における $m$ は 1 リンク移動マニピュレータの質量を表す.

$$
\begin{aligned}
& d_{v}=\mu_{v} v+\mu_{s c} N \operatorname{sign}(v) \\
& N=m g \cos (\alpha) \\
& \mu_{s c}= \begin{cases}\mu_{c}+\mu_{s} \exp (-a|v-b|) & |v| \geq b \\
\mu_{c}+\mu_{s} & |v|<b\end{cases} \\
& v=\sqrt{\dot{x}^{2}+\dot{z}^{2}}, d_{x}=d_{v} \cos (\alpha), d_{z}=d_{v} \sin (\alpha), d_{1}=\mu_{1} \dot{\theta}
\end{aligned}
$$




\section{4 目標軌道の探索方法}

車載リンクの目標軌道である $\theta_{1 d}(t)$ は, 式 (6) に示す ようにフーリ工級数を利用して作成される.つまり, 車載 リンクの目標軌道は周期関数となる.ここで, 式 (6) にお いて $T$ は周期, $a_{0} / 2$ は関数の平均值を表し, $a_{n}, b_{n}(n=$ $1 \sim \infty)$ はフーリ工係数を表す.

$$
\theta_{1 d}(t)=\frac{a_{0}}{2}+\sum_{n=1}^{\infty}\left\{a_{n} \cos \left(\frac{2 n \pi}{T} t\right)+b_{n} \sin \left(\frac{2 n \pi}{T} t\right)\right\}
$$

フーリエ級数のパラメータである $T, a_{0}, a_{1}, b_{1}, \cdots, a_{m}, b_{m}$ を固体の遺伝子情報とし， $G A$ によって組み合わせと最適值を探索させる.第 $j$ 世 代の第 $i$ 固体の遺伝子を式 (7) に示す.

$$
\boldsymbol{g}_{j}^{i}=\left[T_{j}^{i}, a_{0 j}^{i}, a_{1 j}^{i}, b_{1 j}^{i}, \cdots, a_{m j}^{i}, b_{m j}^{i}\right] .
$$

遺伝子を持つ固体を $G A$ により進化させるには各個体を 評価する基準が必要である.今回の運動目的は, 1リン ク移動マ三ピュレータが，波状路面上の凹部から運動を 開始し，決められた方向に，1つ以上の凸部を乗り越え ていく事である. 各個体の評価值は, 固体の遺伝子情報 より作成された目標軌道から, 式 (8) に示す $P D$ 制御に より車載リンクへの入カトルクを計算し，ある一定時間 1リンク移動マニピュレータを運動させた結果より計算 する.この表価值を計算する評価関数を式 (9) に示す.

$\tau_{1}=d_{p}\left(\theta_{1 d}-\theta_{d}\right)+d_{d}\left(\dot{\theta}_{1 d}-\dot{\theta}_{d}\right)$

ここで，式 (9) において, $H$ は評価値を計算する運動シ ミュレーションを行う時間を示し,$x_{j}^{i}(t)$ は式 (1) での計 算結果である，運動の開始位膡は常に波状路面の凹部と なっているため, 式 (9)の $f_{j}^{i}$ がより大きな值をとる事は, 1リンク移動マニピュレータが運動開始位置からより離 れた場所により長時間いる事を意味する。

$$
f_{j}^{i}=\int_{0}^{H} x_{j}^{i}(t) d t
$$

\section{5 シミュレーション}

\section{1 探索シミュレーション}

1 リンク移動マニピュレータを運動させる波状路面と して, $z=0.1(1.0-\cos (4 x))$ を用意し， $G A$ により波 状路面上の凸部を乗り越えて移動していく事を実現させ る車載リンクの目標軌道を探索させた。 $G A$ の各個体に おいて, 1 リンク移動マ三ピュレータの運動開始位置は $[x, z]=[0.0,0.0]$ とする. つまり, 波状路面上の凹部から 運動が開始される事を意味する. $G A$ のパラメー夕は, 個 体数: $p=10,2$ 点交差率: $c(\%)=50$, 淘汰率: $s(\%)=$ 60 , 突然変異率: $m(\%)=30$ と設定した. 又. 今回使 用するフーリエ係数は第 1 項までとし, 各パラメータを 6bits で表現した.この事を式 (10)に示す.

$$
\boldsymbol{g}_{j}^{i}=\overbrace{\underbrace{101011}_{6 b i t s}}^{T_{j}^{i}} \overbrace{\underbrace{010010}_{6 b i t s}}^{a_{0}{ }_{j}^{i}} \overbrace{\underbrace{01110}_{6 b i t s}}^{a_{1}^{i}{ }_{j}^{i}} \overbrace{\underbrace{b_{10101}}_{6 b i t s}}^{b_{1}^{i}}
$$

探索シミュレーションの終了条件を, "1 リンク移動マニ ピュレータが，運動開始位置から10以上の凸部を乗り越 えた位置に，運動終了時到達していれば終了”と設定し探 索させた.

\section{2 運動シミュレーション}

探索シミュレーションより得られた結果, つまりフーリ 工級数のパラメータを利用した1リンク移動マニピュレー 夕の運動を Fig.3 - Fig.6に示す. 探索シミュレーションよ り得られたフーリ工級数のパラメータは, $T=1.695, a_{0}=$ $-0.533, a_{1}=-0.00667, b_{1}=2.84$ である. Fig.3 は時間 経過と台車重心置の $x$ 座標值の関係を, Fig.4は時間経 過と台車重心置の $z$ 座標値の関係を示している. Fig.5 は 車載リンクの運動を示し,Fig.6 は 1 リンク移動マ三ピュ レー夕の移動軌跡を示している.今回の波状路面関数は $z=0.1(1.0-\cos (4 x))$ であるから, 台車重心の $z$ 座標值 が 0.2 をとれば 1 リンク移動マニピュレータが凸部頂上 に到達したことを意味する。

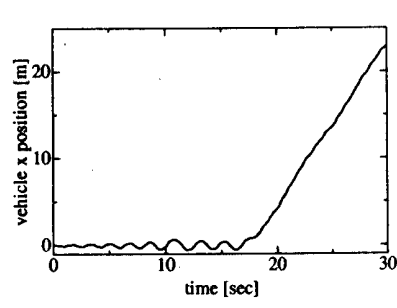

Fig. 3: $\mathrm{x}$ position

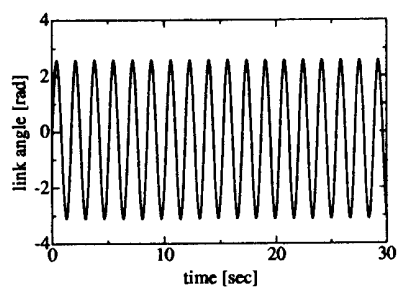

Fig. 5: link angle

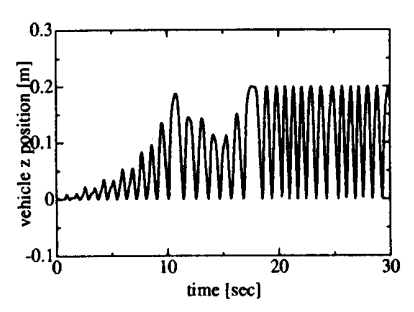

Fig. 4: z position

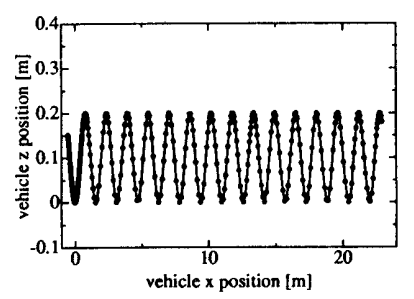

Fig. 6: MM trajectory

\section{6 結言}

本報では，1 リンク移動マニピュレータが，波状路面上 の凸部を乗り越えつつ走行する車載リンクの目標軌道を， 自ら探索できることを確認できた。いままでは路面が水 平だったため運動の評価に平均速度を利用したが，今回 は路面が波状であるから水平路面のときと同じ評価関数 は利用できなかつた。言い換えれば, 評価関数をどう作 成するかが重要であるという事である.

\section{参考文献}

[1] 見浪, 朝倉, 千田, 朝倉 :”駆動力を持たない移動マ二 ピュレータの動力学的干涉を用いた走行”,第 12 回ア ドバンティ・シンポジウム講演論文集,pp.91-94(1999)

[2] 見浪, 朝倉, 玉村,朝倉 :”動力学的干涉と非線型摩擦を 利用するリンク搭載型走行台車の機械学習の一方法”, 日本ロボット学会誌,vol,19,no.7,pp.97-104(2001)

[3] 見浪, 羽多野, 朝倉 : “凹凸路面を走行する移動マ二 ピュレータの研究（第 1 報, 拘束運動モデルの導出と シミュレーション) ", 機論 C 編,vol.63,no.615,pp.265$272(1997)$

[4] 小林，斉藤，野波,”宇宙ロボットの姿勢制御 (第 1 報，スラス夕ーによる制御）"，機論 C 編,vol.59,no.561,pp.1459-1464(1993)

[5] 清水, 猪岡 :”カルマンフィルタによる個体摩擦の推 定（第 1 報，摩擦のモデルを指定した場合のシミュ レーション実験)”，機論 C 編,vol.53,no.496,pp.26082612(1987) 